\title{
Adenosine and ADP prevent apoptosis in cultured rat cerebellar granule cells
}

\author{
O.V. Vitolo, M.T. Ciotti, C. Galli, T. Borsello, P. Calissano * \\ Institute of Neurobiology C.N.R. Viale C. Marx 15, 00196 Rome, Italy
}

Accepted 7 July 1998

\begin{abstract}
Cerebellar granule cells (CGCs) explanted in vitro undergo death via apoptosis when the concentration of potassium is shifted from 25 $\mathrm{mM}$ to $5 \mathrm{mM}$. We report that adenosine and ADP, which act as neurotransmitters and neuromodulators in the brain, exert in cultured cerebellar granule cells a specific and marked antiapoptotic action with half-maximal effect in the $10-100 \mu \mathrm{M}$ range. The action of adenosine is partly inhibited by the A1AR antagonist 8-cyclopentyl-1,3-dipropylxanthine (DPCPX) and is mimicked by the A1AR agonist 2-chloro-N6-cyclopentyladenosine (CCPA), while ADP effect, that is completely blocked by the P2x, P2y receptors noncompetitive antagonist suramine, is restored in the presence of the selective P2x purinoceptors agonist $\beta, \gamma$-methylene-L-ATP. These findings demonstrate that adenosine and ADP markedly inhibit the program of cell death in cerebellar granule cells and suggest that such an action is mediated via interaction with, respectively, A1 and P2x receptors. (C) 1998 Elsevier Science B.V. All rights reserved.
\end{abstract}

Keywords: Cerebellar granule cell; Apoptosis; Purinoceptor; Adenosine; ADP

We have previously reported that lowering extracellular $\mathrm{K}^{+}$from $25 \mathrm{mM}$ to $5 \mathrm{mM}$ triggers apoptosis in cultured rat cerebellar granule cells [6] via a partial closure of L-type $\mathrm{Ca}^{2+}$ channels with consequent drop of intracellular concentrations of this cation [8]. Pharmacological treatments that counteract the $\mathrm{Ca}_{\mathrm{i}}^{2+}$ drop block apoptosis, while antagonists of L-type $\mathrm{Ca}^{2+}$ channels, such as nifedipine, cause apoptosis even in $25 \mathrm{mM} \mathrm{K}^{+}$[8]. It has been reported that cyclic ADP ribose (cADPR) releases $\mathrm{Ca}^{2+}$ in various cell types and its production is achieved by CD38, a type II transmembrane glycoprotein with properties of bifunctional ectoenzyme which is present also in cerebellar granule cells (CGCs) [5].

In view of the crucial role played by $\mathrm{Ca}_{\mathrm{i}}^{2+}$ homeostasis in these neurons and of the action of cADPR in inducing release of this cation from intracellular stores, we tested the possibility that this cyclic nucleotide and its precursor $\beta N A D$ could counteract the apoptotic pathway. Since only $\beta N A D$, but not $\mathrm{cADPR}$, showed a significant and reproducible neuroprotective action (see also Fig. 1), a systematic search for the active component of this compound responsible of the antiapoptotic action was undertaken and led to identify adenosine and ADP as the constituents fully endowed with the antiapoptotic activity.
Since nucleotides and nucleosides have been shown or postulated to play also the function of trophic substances [16], besides a neurotransmitter and neuromodulatory role, the marked and specific antiapoptotic action exerted on CGCs first reported in this paper could have relevance to all conditions whereby a control of the program of cell death could play a crucial role. Among these are the events controlling the extent and site(s) of cell death during development, when approximately 50\% of neurons are doomed to die during formation of neural networks and several neurodegenerative disorders affecting the adult brain.

Cultures enriched in granule neurons were obtained from dissociated cerebella of eight-day-old Wistar rats (Charles River Breeding Laboratories), according to the procedure previously described [13]. Cells were plated in basal medium Eagle (BME; GIBCO) supplemented with fetal bovine serum (FBS) on four-well dishes (NUNC) previously coated with poly-L-lysine $(10 \mu \mathrm{g} / \mathrm{ml})$. Cellular density was $0.5 \times 10^{6}$ cells per well. After $18-22 \mathrm{~h}$, $1-\beta$-arabinofuranosylcytosine $(10 \mu \mathrm{M})$ was added to the culture medium to prevent replication of non-neuronal cells.

In order to induce apoptosis, after 6-7 DIV, the culture medium containing $25 \mathrm{mM} \mathrm{KCl}$ was replaced with an identical medium devoid of serum and containing $5 \mathrm{mM}$ $\mathrm{KCl}[6]$ plus or minus (controls) the substance tested for its possible antiapoptotic action. The antagonists were added

\footnotetext{
* Corresponding author. Fax: +39-6-86090370
} 

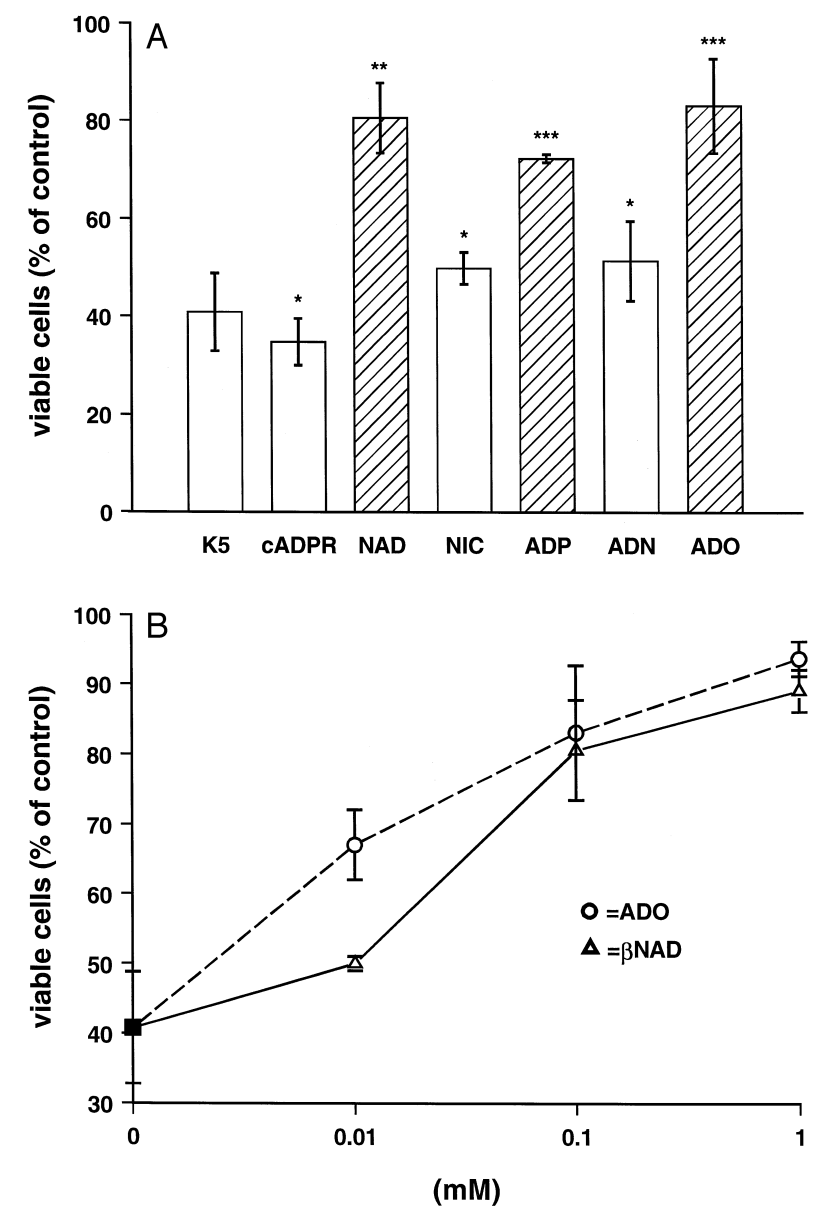

Fig. 1. (a) Survival of neurons in $5 \mathrm{mM} \mathrm{KCl}$ after treatment with various agents. Induction of apoptosis was performed switching 6 DIV-cultured cerebellar granule cells from culture medium containing 10\% FBS and 25 $\mathrm{mM} \mathrm{KCl}$ to serum-free medium with $5 \mathrm{mM} \mathrm{KCl}$ and no additives (K5) or with $10 \mu \mathrm{M}$ cyclic ADPR (cADPR), $100 \mu \mathrm{M} \beta$ NAD (NAD), $100 \mu \mathrm{M}$ nicotinamide (NIC), $100 \mu \mathrm{M}$ ADP, $100 \mu \mathrm{M}$ adenine (ADN), or $100 \mu \mathrm{M}$ adenosine (ADO). Forty-eight hours later, viable cells were counted and compared to controls in serum-free medium containing $25 \mathrm{mM} \mathrm{KCl}$. (b) Concentration dependence of the antiapoptotic action of $\beta N A D$ and adenosine (ADO). Cells treated as above were tested with different concentrations of $\beta$ NAD and adenosine. Forty-eight hours later, viable cells were counted and compared to controls. The maximum antiapoptotic activity is achieved at $1 \mathrm{mM}$, whereas half-maximal effect occurs in the 10-100 $\mu \mathrm{M}$ range. Each bar represents mean \pm S.D. Statistically significant differences were estimated with Duncan's multiple range test. $* D=$ n.s. compared to $\mathrm{K} 5$; $* * D=\mathrm{s}$. compared to $\mathrm{K} 5$; $* * * D=$ n.s. compared to $100 \mu \mathrm{M} \beta \mathrm{NAD}$. The experiments were repeated four times in duplicate with different cell preparations $(n=4)$.

15 min before addition of corresponding agonists. Controls underwent the same procedure, but their medium contained $25 \mathrm{mM} \mathrm{KCl}$.

After 24 or $48 \mathrm{~h}$ of incubation in $5 \mathrm{mM} \mathrm{KCl}$ and 25 $\mathrm{mM} \mathrm{KCl}$ medium, viable cells were determined by counting intact nuclei at contrast phase microscope as previously described [23] or were processed for TUNEL (terminal UTP end labeling) in order to detect DNA degradation typical of apoptosis. To this aim, the cells were fixed for $10 \mathrm{~min}$ in $4 \%$ paraformaldehyde, rinsed in Tris-EDTA 0.5 $\mu \mathrm{g} / \mathrm{ml}$ (TE), briefly processed in TdT buffer $(25 \mathrm{mM}$ Tris- $\mathrm{HCl}, 200 \mathrm{mM}$ sodium cacodylate, $5 \mathrm{mM}$ cobalt chloride) and subsequently incubated with the labeling mix (20 $\mathrm{U}$ TdT-Boehringer, $0.5 \mathrm{nmol}$ digoxigenin-11-ddUTPBoehringer in $100 \mu \mathrm{l} \mathrm{TdT}$ buffer) for $120 \mathrm{~min}$ at $37^{\circ} \mathrm{C}$. After the TdT reaction, the cells were rinsed in Trisbuffered saline (TBS), incubated in TBS containing 0.3\% Triton X-100 and 2\% bovine serum albumin for $60 \mathrm{~min}$ with anti-digoxigenin Fab fragments conjugated with alkaline phosphatase (Boehringer) diluted $1 / 250$ in TBS-Triton. After washing in TBS, the colour reaction was visualised by incubating the cells in colour buffer $(100 \mathrm{mM}$ Tris- $\mathrm{HCl}, 100 \mathrm{mM}$ sodium chloride, $50 \mathrm{mM}$ magnesium chloride, $\mathrm{pH}$ 9.5) containing 4-nitroblue tetrazolium salt and 5-bromo-4-chloro-3-indolyl phosphate (Boehringer). The reaction was monitored under the microscope and stopped in TE. The labeled cells withstand intensive cells washings providing evidence that ddUTP is covalently incorporated by the TdT and that DNA breaks appearing in apoptotic cells really function as primer for the in situ reaction.

Data analysis was performed with Stat-100 software (Biosoft). Each test was repeated four or five times in duplicate (see the figure legends) and collected results were processed with One-way analysis of variance (ANOVA) for repeated measurements. If the effect was significant $(p=0.05)$ Duncan's multiple range test posthoc analysis was used for multiple comparison of means $(p<0.05$ was considered to indicate a significant difference). Further, $D=\mathrm{s}$. will be used for a significant Duncan's test result, while $D=$ n.s. for a not significant one, compared to controls when not specified.

Adenosine, ADP, $\beta N A D$, and DPCPX were from Sigma. Suramine, CCPA, DPMA, CSC, $N^{6}$-benzyl-NECA, Reactive-blue 2 and $\beta, \gamma$-methylene-L-ATP were from RBI.

In a preliminary series of experiments, 6-7 DIV-cultured cerebellar granule cells were switched in $5 \mathrm{mM} \mathrm{KCl}$ (K5) serum-free medium in the absence or in the presence of cADPR and of its precursor $\beta N A D$. After $24 \mathrm{~h}$, the extent of cell death via apoptosis was monitored. As can be seen in Fig. 1a, while cADPR at all concentrations tested $(1 \mu \mathrm{M}, 10 \mu \mathrm{M}, 100 \mu \mathrm{M})$ is not able to block the death process $(D=$ n.s.); on the contrary, $100 \mu \mathrm{M} \beta \mathrm{NAD}$ enhances survival from $40.8 \% \pm 8$ (mean value \pm S.D.) of the controls in $5 \mathrm{mM} \mathrm{KCl}$ to $88.9 \% \pm 3(D=\mathrm{s}$.). In order to assess which constituent of $\beta$ NAD was endowed with the anti-apoptotic action, we separately tested nicotinamide, adenine, adenosine, and ADP (Fig. 1a). We found that neither nicotinamide nor adenine has a significant effect ( $D=$ n.s.), whereas adenosine and ADP exhibit an effect overimpossible to that of $\beta N A D$. Concentration-dependent experiments reported in Fig. 1b indicate that the maximum protective activity is achieved at $1 \mathrm{mM}$ both for $\beta N A D$ and adenosine and that half-maximal effect occurs in the $10-100 \mu \mathrm{M}$ range. The slightly lower activity of $\beta N A D$ at all concentrations tested is probably attributable 
to the fact that in order to be active, it must be first degraded to adenosine by nucleotidase present in the cytoplasmic membrane. The experimental test based on the evaluation of the extent of cell death does not allow to calculate in a more precise fashion the concentration providing half-maximal protection.

Parallel experiments performed with the TUNEL procedure (Fig. 2) confirm and extend previous findings that the $25 \mathrm{mM}$ to $5 \mathrm{mM} \mathrm{KCl}$ shift causes death via apoptosis characterized by DNA laddering due to fragmentation into internucleosomal particles [6]. We found that only a fraction of all neurons that, at any given time, have undergone apoptotic death are labeled with this technique, suggesting that only for a limited time window neurons undergoing apoptosis are available for nick end labeling. As shown in Fig. $2 c, d$, in the presence of $\beta$ NAD and adenosine, labeled neurons are barely detectable, and are comparable to controls kept in $25 \mathrm{mM} \mathrm{KCl}$.

Moreover, morphological examinations at phase contrast microscope (not shown) indicate that cultures main-
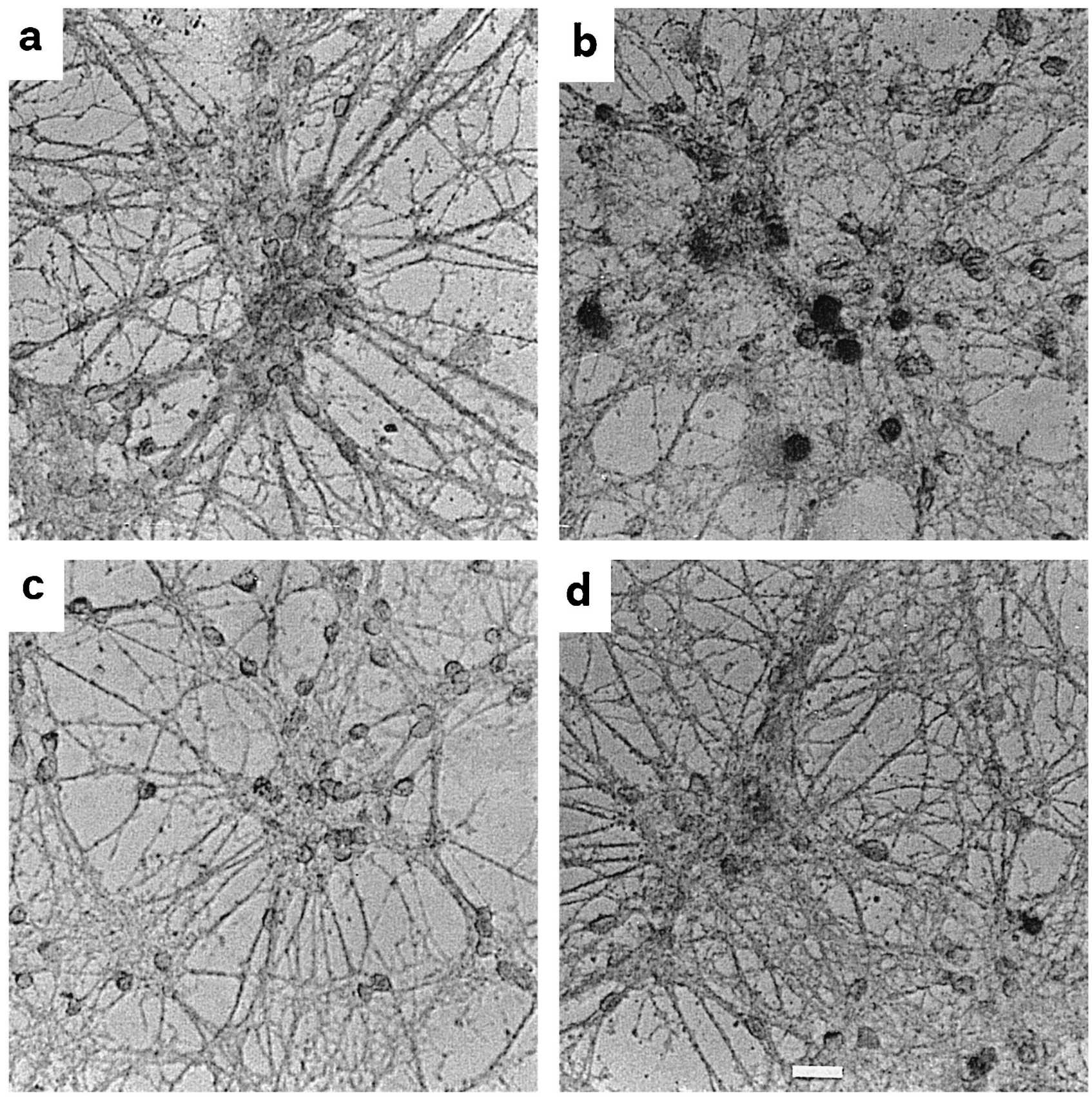

Fig. 2. Prevention of low KCl-induced apoptosis by $\beta N A D$ and adenosine revealed by TUNEL staining. Six DIV neurons were shifted in low KCl (5 mM) serum-free medium, in the absence (b) or in the presence of $100 \mu \mathrm{M} \beta \mathrm{NAD}$ (c) or $100 \mu \mathrm{M}$ adenosine (d). Forty-eight hours later, cultures were processed with TUNEL technique to detect dead cells and photographed using an inverted light microscope. (a) Control in $25 \mathrm{mM}$ serum-free medium. Experiments were repeated three times with similar results, thus, pictures are representative fields. Scale bar (shown in d): $10 \mu \mathrm{m}$. 
tained for $48 \mathrm{~h}$ in $5 \mathrm{mM} \mathrm{KCl}$ medium supplemented with $\beta N A D$, adenosine, and ADP are populated by a number of healthy neurons comparable to that detectable in $25 \mathrm{mM}$ $\mathrm{KCl}$, with well-defined cell bodies and a developed network of neurites, while detached cells, shrunken bodies, and fragmented neurites are rare in all fields.

Attempts were therefore performed to assess the type of adenosine receptor responsible of this antiapoptotic activity, considering that previous studies had shown that A1 adenosine receptors are predominantly expressed in cerebellum and particularly in CGCs [20,25] and involved in the neuroprotective activity of purines [14] and that ADP induces $\mathrm{Ca}^{2+}$ influx via $\mathrm{P} 2 \mathrm{x}$ receptors $[12,22]$. To this aim, the A1AR antagonist 8-cyclopentyl-1,3-dipropylxanthine (DPCPX) [3,17], the A1AR agonist 2-chloro-N6-cyclopentyladenosine (CCPA) [11,17] and the noncompetitive $\mathrm{P} 2 \mathrm{x}, \mathrm{P} 2 \mathrm{y}$ receptors antagonist suramine [4] were used. As it can be seen in Fig. 3, in the presence of $10 \mu \mathrm{M}$ CCPA, neurons survive $(80.0 \% \pm 6.0 ; D=\mathrm{s}$. compared to $5 \mathrm{mM}$ $\mathrm{KCl})$ to an extent overimpossible to that occurring with ADP and slightly lower than with adenosine $(86.0 \% \pm 6.0$; $D=$ n.s. compared to $100 \mu \mathrm{M}$ adenosine). On the other hand, $200 \mu \mathrm{M}$ DPCPX only in part reverses adenosine neuroprotection $(68.0 \% \pm 6.0 ; D=\mathrm{s}$. compared with 100 $\mu \mathrm{M}$ adenosine), while suramine completely inhibits the protection of ADP $(35.0 \% \pm 3.0 ; D=$ n.s. compared to 5 $\mathrm{mM} \mathrm{KCl}$ ). Controls in $25 \mathrm{mM} \mathrm{KCl}$ and in $5 \mathrm{mM} \mathrm{KCl}$ media with DPCPX or suramine alone show that these substances have no toxic effect at the concentrations employed in these studies (not shown). In order to assess the possible role of the other types of adenosine receptors and

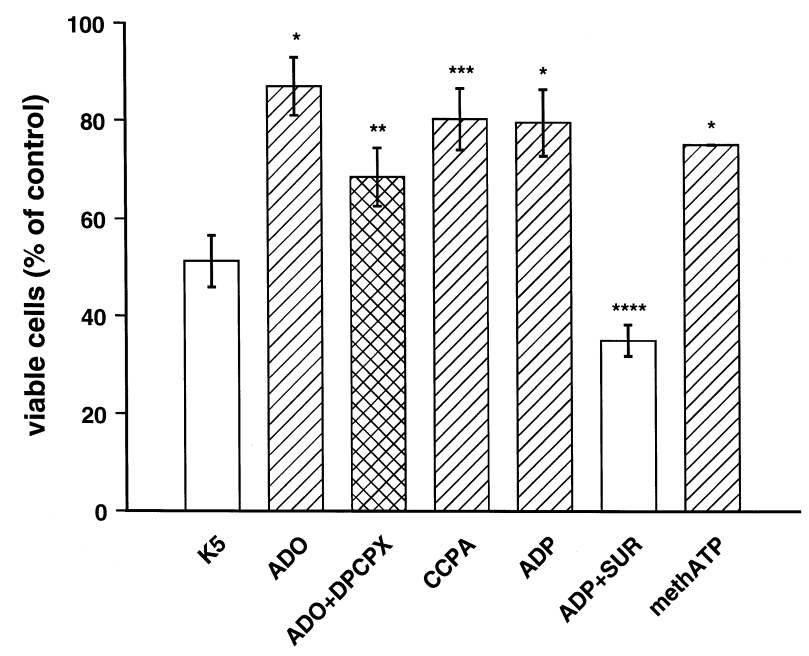

Fig. 3. Survival of neurons after $24 \mathrm{~h}$ of treatment in low $\mathrm{K}^{+}$without additives (K5) or with adenosine (ADO, $100 \mu \mathrm{M}$ ) alone or with the A1AR antagonist DPCPX $(200 \mu \mathrm{M})$, with the A1AR agonist CCPA (10 $\mu \mathrm{M}$ ), with $100 \mu \mathrm{M}$ ADP alone or with the noncompetitive P2x, P2y antagonist suramine (SUR, $100 \mu \mathrm{M}$ ), with the selective $\mathrm{P} 2 \mathrm{x}$ receptor agonist $\beta, \gamma$-methylene-L-ATP (methATP, $100 \mu \mathrm{M}$ ). $* D=\mathrm{s}$. compared to $\mathrm{K} 5 ; * * D=\mathrm{s}$. compared to $100 \mu \mathrm{M}$ ADO; $* * * D=$ n.s. compared to $100 \mu \mathrm{M} \mathrm{ADO} ; * * * * D=\mathrm{s}$. compared to $100 \mu \mathrm{M}$ ADP. Values are means of five experiments repeated in duplicate $(n=5)$. which of the two $\mathrm{P} 2$ receptors subtypes recognized by suramine is responsible of ADP protection, we used the A2AR agonist $N^{6}$-2-(3,5-dimethoxyphenyl)-2-2-methylphenyl-ethyl adenosine (DPMA), the A2 $\mathrm{a}$ AR antagonist 1,3,7-trimethyl-8-(3-chlorostyryl) xanthine (CSC) alternatively in association with DPMA and adenosine, the selective A3AR agonist $N^{6}$-benzyl-5'- $N$-ethylcarboxamidocadenosine ( $N^{6}$-benzyl-NECA), the P2y receptor antagonist Reactive-blue 2 and the $\mathrm{P} 2 \mathrm{x}$ receptor agonist $\beta, \gamma$-methylene-L-ATP $[12,17]$. Ten micromolars of DPMA $(37.4 \% \pm$ 6.2; $D=$ n.s.), $10 \mu \mathrm{M}$ and $100 \mu \mathrm{M} N^{6}$-benzyl-NECA $(47.6 \% \pm 6.4 ; D=$ n.s.) did not influence the viability of the neurons, while $100 \mu \mathrm{M}$ DPMA had a toxic action. On the other hand, $100 \mu \mathrm{M}$ adenosine was not antagonized by the addition of $200 \mu \mathrm{M} \mathrm{CSC}(72.0 \% \pm 3.3 ; D=$ n.s. compared to $100 \mu \mathrm{M}$ adenosine), therefore, ruling out the participation of $\mathrm{A} 2$ and $\mathrm{A} 3$ receptors in the neuroprotective activity. As far as suramine inhibition of ADP action is concerned, we observed that Reactive-blue 2 exerts a toxic effect on granule cultures at all tested concentrations (20, $100,200 \mu \mathrm{M})$ whereas $\beta, \gamma$-methylene-L-ATP elicits a protective activity already at $10 \mu \mathrm{M}(63.0 \% \pm 4.2 ; D=$ n.s. compared to $10 \mu \mathrm{M}$ ADP) reaching ADP protection level at $100 \mu \mathrm{M}(75.0 \% \pm 0.0 ; D=$ n.s. compared to 100 $\mu \mathrm{M}$ ADP) (Fig. 3).

The findings reported in this paper demonstrate that adenosine and ADP inhibit the proapoptotic stimulus of low extracellular $\mathrm{KCl}$ in a concentration-dependent fashion with half-maximal effect at $10-100 \mu \mathrm{M}$ and a plateau at $1.0 \mathrm{mM}$. It has been reported [15] that adenosine acts as an endogenous activator of the cellular antioxidant system and that reactive oxygen species (ROS) are produced during apoptosis. Our data suggest that the antiapoptotic action of adenosine and ADP could be achieved via inhibition of ROS production during early stages of apoptosis and that this effect is mediated by the interaction of these ligands with their receptors. Another action of adenosine and ADP could consist in restoring ATP levels which are generally impaired during apoptosis in several cell systems [19]. The question then arises as to the possible biological significance of this effect and of the mechanism through which it is reached. The observations that CCPA can mimic adenosine properties, DPCPX partially antagonizes its antiapoptotic action, and that $\beta, \gamma$-methylene-L-ATP inhibits the death of neurons to the same extent as ADP, suggest the involvement of both A1AR and P2x purinoceptors. Future studies should clarify this problem and elucidate whether the antiapoptotic action is achieved by restoration of $\mathrm{Ca}^{2+}$ homeostasis imbalanced by the $\mathrm{Ca}_{\mathrm{i}}^{2+}$ drop caused by potassium withdrawal from culture medium [8] or, alternatively, via activation of alternate pathway(s) downstream the $\mathrm{Ca}_{\mathrm{i}}^{2+}$ drop.

As for the possible functional significance, it is worth mentioning that adenosine is released in vitro by CGCs [21], that low concentrations of this nucleoside are present in vivo in the extracellular space and that several physio- 
logical or pathological stimuli may cause its rise via a bidirectional facilitated diffusion [9] or via extracellular degradation of ATP [24]. Furthermore, electrical and chemical depolarization [2,7] or ischemia-hypoxic conditions $[3,10]$ evoke adenosine release in the extracellular space where it can exert its action both at pre- and post-synaptic sites by inhibiting the release of excitatory neurotransmitters $[1,18]$ and by decreasing EPSP (excitatory post-synaptic potential) via A1ARs [26].

Thus, adenosine and its derivatives may exert their action not only as neurotransmitters and neuromodulators, but also by stabilizing neuronal functions via different routes consisting in provoking vasodilation to supply oxygen and nutrients [21], inhibiting excitotoxicity by neurotransmitters and preventing neurons from delayed death via apoptosis as reported in this paper.

\section{Acknowledgements}

We thank Dr. Delio Mercanti for useful discussions. This work has been financed in part with a grant from Progetto Finalizzato Biotecnologie and in part with a grant obtained with a research contract with NE.FA.C., Pomezia, Italy, within the National Plan Neurobiological Systems of the Ministero della Università e della Ricerca Scientifica e Tecnologica.

\section{References}

[1] J.M. Brundege, V.T. Dunwiddie, Modulation of excitatory synaptic transmission by adenosine released from single hippocampal pyramidal neurons, J. Neurosci. 16 (1996) 5603-5612.

[2] M.C. Cahill, T.D. White, J. Sawynok, Involvement of calcium channels in depolarization-evoked release of adenosine from spinal cord synaptosomes, J. Neurochem. 60 (1993) 886-893.

[3] P. Canhao, A. de Mendoça, J.A. Ribeiro, 1,3-Dipropyl-8-cyclopentylxanthine attenuates the NMDA response to hypoxia in the rat hippocampus, Brain Res. 661 (1994) 265-273.

[4] K. Chang, K. Hanaoka, M. Kumada, Y. Takuwa, Molecular cloning and functional analysis of a novel P2 nucleotide receptor, J. Biol. Chem. 270 (1995) 26152-26158.

[5] A. De Flora, L. Guida, L. Franco, E. Zocchi, M. Pestarino, C. Usai, C. Marchetti, E. Fedele, G. Fontana, M. Raiteri, Ectocellular in vitro and in vivo metabolism of cADP-ribose in cerebellum, Biochem. J. 320 (1996) 665-672.

[6] S.R. D'Mello, C. Galli, M.T. Ciotti, P. Calissano, Induction of apoptosis in cerebellar granule neurons by low potassium: inhibition of death by insulin-like growth factor I and cAMP, Proc. Natl. Acad. Sci. USA 90 (1993) 10989-10993.

[7] B.B. Fredholm, K. Lindstrom, A. Wallman-Johansson, Propentofylline and other adenosine transport inhibitors increase the efflux of adenosine following electrical or metabolic stimulation of rat hippocampal slices, J. Neurochem. 62 (1994) 563-573.

[8] C. Galli, O. Meucci, A. Scorziello, T.M. Werge, P. Calissano, G.
Schettini, Apoptosis in cerebellar granule cells is blocked by high $\mathrm{KCl}$, forskolin, and IGF-1 through distinct mechanisms of action: the involvement of intracellular calcium and RNA synthesis, J. Neurosci. 15 (1995) 1172-1179.

[9] J.G. Gu, I.O. Foga, F.E. Parkinson, J.D. Geiger, Involvement of bidirectional adenosine transporters in the release of $\mathrm{L}^{3} \mathrm{H}$ adenosine from rat brain synaptosomal preparations, J. Neurochem. 64 (1995) $2105-2110$

[10] H. Hagberg, P. Andersson, J. Lacarewicz, I. Jacobson, S. Butcher, M. Sandberg, Extracellular adenosine, inosine, hypoxanthine, and xanthine in relation to tissue nucleotides and purines in rat striatum during transient ischemia, J. Neurochem. 49 (1987) 227-231.

[11] D. Janigro, R. Wender, G. Ransom, D.L. Tinklepaugh, H.R. Winn, Adenosine-induced release of nitric oxide from cortical astrocytes, NeuroReport 7 (1996) 1640-1644.

[12] T. Kendall Harden, J.L. Boyer, R.A. Nicholas, P2-purinergic receptors: subtype-associated signaling responses and structure, Annu. Rev. Pharmacol. Toxicol. 35 (1995) 541-579.

[13] G. Levi, F. Aloisi, M.T. Ciotti, V. Gallo, Autoradiographic localization and depolarization-induced release of acidic amino acids in differentiating cerebellar granule cell cultures, Brain Res. 290 (1994) $77-86$.

[14] D.G. Macgregor, T.W. Stone, Blockade by 1,3-dipropyl-8-cyclopentylxanthine (CPX) of purine protection against kainate neurotoxicity, Brain Res. 644 (1994) 339-342.

[15] S.B. Maggiwar, D.N. Dhanraj, S.M. Somani, V. Ramkumar, Adenosine acts as an endogenous activator of the cellular antioxidant defense system, Biochem. Biophys. Res. Commun. 201 (2) (1994) $508-515$.

[16] J.T. Neary, M.P. Rathbone, F. Cattabeni, M.P. Abbracchio, G. Burnstock, Trophic actions of extracellular nucleosides and nucleotides on glial and neuronal cells, Trends Neurosci. 19 (1996) $13-18$.

[17] M.E. Olah, G.L. Stiles, Adenosine receptor subtypes: characterization and therapeutic regulation, Annu. Rev. Pharmacol. Toxicol. 35 (1995) 581-606.

[18] D.A. Prince, C.F. Stevens, Adenosine decreases neurotransmitter release at central synapses, Proc. Natl. Acad. Sci. USA 89 (1992) $8586-8590$.

[19] C. Richter, M. Schweizer, A. Cossarizza, C. Franceschi, Control of apoptosis by the cellular ATP level, FEBS Lett. 378 (2) (1996) $107-110$.

[20] J.M. Sanz, D. Vendite, M. Fernandez, A. Andrés, M. Ros, Adenosine A1 receptors in cultured cerebellar granule cells: role of endogenous adenosine, J. Neurochem. 67 (1996) 1469-1477.

[21] M.I. Sweeny, Adenosine release and uptake in cerebellar granule neurons both occur via an equilibrative nucleoside carrier that is modulated by G proteins, J. Neurochem. 67 (1996) 81-88.

[22] S. Valera, N. Hussy, R.J. Evans, N. Adami, R.A. North, A. Surprenant, G. Buell, A new class of ligand-gated ion channel defined by P2X receptor for extracellular ATP, Nature 371 (1994) 516-519.

[23] C. Volontè, M.T. Ciotti, L. Battistini, Development of a method for measuring cell number: application to CNS primary neuronal cultures, Cytometry 17 (1994) 274-276.

[24] T.D. White, K. Hoehn, Release of adenosine and ATP from nervous tissue, in: T.W. Stone (Ed.), Adenosine in the Nervous System, Academic Press, London, 1991, pp. 173-195.

[25] W.J. Wojcik, N.H. Neff, Adenosine A1 receptors are associated with cerebellar granule cells, J. Neurochem. 41 (1983) 759-763.

[26] L.G. Wu, P. Saggau, Adenosine inhibits evoked synaptic transmission primarily by reducing presynaptic calcium influx in area CA1 of hippocampus, Neuron 12 (1994) 1139-1148. 